\title{
BETWEEN SOCIAL HUMANISM AND SOCIAL MOBILIZATION The Dual Role of Madrasah in the Landscape of Indonesian Islamic Education
}

\author{
Sunhaii \\ IAIN Purwokerto - Indonesia | a.sunhaji@gmail.com
}

\begin{abstract}
This article analyzes the dual as well as overlapping role of madrasab in the history of Indonesian Islamic education. It argues that madrasah has long been playing the double roles at once; on the one hand it has served as the enlightening process of Indonesian Islam by giving a sense of moderation. It also has paved the way for the accommodation of non-religious subjects within its existing religious ones. In this sense, madrasah has played its social humanism. Madrasah, however, has been an effective means of power struggle as well as social mobilization among Muslims into the center of socio-political spheres. As Indonesian Muslims have long been marginalized by non-Islamic schooling system, madrasah has helped them struggle from their marginality through the emancipation and participation programs launched by madrasab. Muslims have been incessantly fought for their equality in terms of madrasab's legal status and demanded more equal treatment from the state. In effect, the enactment of the Law No. 2/1989 marks a radical shift in the direction of Islamic education in Indonesia which is celebrated by the community of madrasah as a new era for their autonomy and equal status before the state.
\end{abstract}

Keywords: madrasah, social humanism, social mobilization, Islamic education, Indonesian Islam.

\section{Introduction}

It should be stressed from the beginning that madrasah (Islamic schooling) have played important role in the transformation of Indonesian community by educating them in exact science as well as 
religious knowledge. This in turn creates balance between intellectualism and spirituality for the formation of a civilized person. The emergence of madrasab in Indonesia during Dutch colonial period, according to Abuddin Nata, was a reaction to Dutch education system which was privileged for certain classes, leaving Muslims behind. Thus several Muslims aspired to provide excellent education from Muslim community. From then on, madrasah as well as pesantren (traditional Islamic boarding school) are two formidable educational institutions for Indonesian Muslims. These two institutions have produced plenty of Indonesian Muslim leading personalities. It is not an exaggeration that madrasah is an important pillar for Indonesian education, especially for those marginalized whose right to education is denied.

Up to now, the existence of madrasah remains the most influential education institution for Muslims. There has been several types of adjustments and adaptations done by madrasah in response to modernization in many respects. ${ }^{1}$ Admittedly, the major contribution of madrasah has been the education for the less privileged who could not afford the access and finance of national education. This crucial role, however, does not meet with equal recognition from the government as well as Indonesian community at large. Madrasah is considered as lagged behind in terms of academic quality compared to schools under national educational system. Some analysts even states that madrasah should get serious attention and support. ${ }^{2}$ In this aspect, it is interesting to study the existence of madrasah which is a reflection of flexible social awareness of Indonesian Muslim community to conduct social humanism and social mobilization at one time.

When highlighted closely, many madrasabs are created by Muslim mass organization such as Muhammadiyah and Nahdlatul Ulama, by Islamic foundation, as well as by philantpropic personalities and organizations. In this sense, madrasah sometimes represents idealogical leanings of its founder. With reasonably inexpensive fees or even free of charge, madrasab is the destination for poorer segment of Indonesian community. Madrasab also place where the less talented students can get access to education. Since access is their rimary role, quality is not

\footnotetext{
${ }^{1}$ Ismail SM, Nurul Huda, and Abdul Kholiq (eds), Dinamika Pesantren dan Madrasah (Semarang: Fakultas Tarbiyah IAIN Walisongo in collaboration with Pustaka Pelajar, 2002), p. xxi.

${ }^{2}$ Kahar, "Pendidikan Islam dalam Pandangan Pendidikan Nasional," Jurnal Al-Qolam, 8:1 (2016).
} 
priority. However, with this limitation, madrasah has become medium of knowledge transfer and civility.

Apart from the role madrasah has played as a means of creating the social humanism, the course it has taken creates a by-product role of madrasah as an effective means of social mobilization among Indonesian Muslims. As many observers has noted, the birth and growth of madrasah cannot be separated from the two motifs: 1). the reform project launched by modernist Muslims in response to the backwardness of Indonesian Muslims in general, and; 2). The marginalization of Muslims from public schools founded by the Dutch. ${ }^{3}$ In order to achieve a better life in socio-political aspects, Muslims sought to build a strong educational institution that could accommodate them. One of the forms of such an educational institution is madrasah, similar to formal schooling in the Dutch educational system, in addition to pesantren, a long established mode of educational system.

This article attempts at uncovering the fact that madrasah has played its dual as well as overlapping role in creating social humanism and social mobilization among Muslims. Until now, the implementtation of social humanism in madrasab is widely rekognized. In addition, this humanism is not yet conducted throroughly, it just touched the the model of education, according to Subiyantoro, ${ }^{4}$ whereas the manifesttation of social humanism is a reflection of collective awareness of Indonesian muslim community in madrasah to equip children with knowledge as well as religious ethic as commanded in Islam to create balance between the two causes. In addition, the article is also aimed at presenting the important role of madrasah in growing intellectual revolution among marginal communities which has been done through the creation of madrasah as well as thought so that all children can access education.

\section{Madrasah and Muslim Community in Indonesia}

The emergence of madrasab initially can be traced back to the tradition of education in the Middle East as further development of Islamic education which was commonly held in mosques and

\footnotetext{
3 Maksum, Madrasab: Sejarah \& Perkembangannya (Jakarta: Logos Wacana Ilmu dan Pemikiran, 1999), pp. 82-97.

4 Subiyantoro, "Pengembangan Model Pendidikan Nilai Humanis-Religius Berbasis Madrasah," Cakrawala Pendidikan, 32:3 (November 2013).
} 
dormitories. ${ }^{5}$ In Indonesia, madrasah is a continuation of pesantren. Education tradition of pesantren initially provided Islamic instruction, especially jurisprudence and quranic recitation. Since there was no instruction of exact science, students of pesatren were lagged behind compared to students of secular schools. As a result, pesantren students cannot compete with students of secular schools in workforce. Having said so, this Islamic education is preferable for many Muslims due to religious and idealogical standpoint. Thus, it is more than a preparation for getting good job, but salvation in hereafter.

Terminologically speaking, the term 'madrasab' originates from Arabic word 'darasa' which means 'to study'.6 So, madrasah means place for study. In Indonesia, madrasah mean schools for Muslims which teaches considerable portion of Islamic instruction, whereas sekolah or schools teaches considerable portion of exact and general science. This dichotomy cannot be separated from the fact that the earlier Islamic education is pesantren which trained students solely to become a cleric or other religious-based expertise. Later in the early twentieth century, madrasah appeared to reform Islamic education by also teaches exact science in addition to Islamic instruction. ${ }^{7}$

The name madrasab actually appeared later for place to study how to recite al-Qur'an, supplication, prayer and other basic Islamic practical rituals for kids and adults. ${ }^{8}$ It is also defined as school based on Islamic teaching. ${ }^{9}$ There was no uniformity among madrasabs in terms of curriculum, duration of study as well as its facilities and resources. In 1975, there was a joint agreement between minister of

5 Baharudin, Umiarso, and Sri Minarti, Dikotomi Pendidikan Islam: Historisitas dan Implikasi pada Masyarakat Islam (Bandung: PT Remaja Rosda Karya, 2011), pp. 219-221.

6 There are many opinions concerning the history of madrasah. In Indonesia, madrasah emerged and became popular after the Dutch introduced schools for local elites in late Eighteenth Century. The Islamic doctrine was present as part of madrasah curriculum since the beginning. Read Sunhaji, Managemen Madrasah (PurwokertoYogyakarta: STAIN Press in collaboration with Grafindo, 2006), p. 74.

7 Azyumardi Azra, et.al., "Pesantren and Madrasa: Muslim Schools and National Ideas in Indonesia", in Robert W. Hefner and Muhammad Qasim Zaman (eds), Schooling Islam: The Culture and Politics of Modern Muslim Education (Princeton, New Jersey: Princeton University Press, 2007), p. 184.

${ }^{8}$ Nurul Huda, "Madrasah: Sebuah Perjalanan untuk Eksis," Ismail SM, Nurul Huda, and Abdul Kholiq (eds), Dinamika Pesantren dan Madrasah, pp. 214-215.

9 Departemen Pendidikan dan Kebudayaan, Kamus Besar Bahasa Indonesia (Jakarta: Gramedia, 2015). 
national education, minister of religious affairs and minister of internal affairs to reform the curriculum of madrasah. Madrasah which was poorly administered under the Ministry of Religious Affairs then was designed to parallel with secular schools. Three level of madrasab then created; madrasah ibtida'iyyah must correspond to elementary school, madrasah tsanawiyah correspond to Junior high school and Madrasah Aliyah corresponds to high school. ${ }^{10}$ The curriculum was designed to accommodate both Islamic instruction as well as exact science. This combination initially was to erase dichotomy of Islamic science and general science, but it turned out to become a distinct identity in Indonesian education.

\section{Madrasah's Social Humanism}

Humanism is perceived as philosophical thought which seeks to extract human values, especially on rights that human being is entitled to in his or her life. In this thought, human being has the privilege of improving his or her life as a human being to become a better person without harming others. Everyone has his or her own needs to life in harmony, ${ }^{11}$ including the need to faith and education. In religious teaching, human being needs faith to hold on. There are religious concepts which govern human being to live peacefully with others. In addition, human being needs education to live across time. The fulfilment of human's needs without harming others who have identical rights is the essence of humanism.

The essence of humanism as an ideology can be discerned though a society that has knowledge resulting from education which is aimed at building better order. ${ }^{12}$ Human being builds civilization on the basis of education. Great past civilizations always weighs more on education than the others. From this respect, morality and ethics should be emphasized because human being cannot life with mere rationality. Humanism founded upon religious values will guide human being to reach a balance between physical aspect of civilization and morality.

\footnotetext{
${ }^{10}$ Marwan Saridjo, Bunga Rampai Pendidikan Agama Islam (Jakarta: CV Amissco, 1996), p. 118.

11 Read for instance Murni Rachmawati, "Humanisme (Kembali) dalam Arsitektur," Nalars, 9:2 (July 2010): pp. 103-116

12 Sri Utami, "Kesadaran Kritis dan Humanisme dalam Globalisasi: Kajian Pemikiran Edward W. Said tentang Worldliness Humanism," in Proceeding the $5^{\text {th }}$ International Conference Indonesian Studies: "Ethnicity and Globalization".
} 
Religion always stresses on morality with which human being should observe, including coexistence with fellow human being. Therefore, Islam always emphasizes the balance between worldly affairs and hereafter.

In the concept of humanism, awareness is a method for human being to act upon what is happening in the surrounding by instinct dan reason based on the crystallized ideology. This awareness appears differently, since it relates to social system and personal belief. This personal conviction and knowledge form distinct awareness to become a humanist. Human being without self-awareness will act like animals and uncontrollable. ${ }^{13}$ This is simply madness. Therefore, every human being has awareness with own perspective. Normative awareness as an awareness which ties someone based on norms and rules consented by society. This awareness exists in the society and a person living in it must obey its rules. This awareness appears because basically human being is a social creature, they need to form consensus and rules to live by.

In religious humanism, normative-religious awareness is the one on a person to believe the existence that religion provides a set of guidance. ${ }^{14}$ One's existence in his or her community is based on religious belief. Human being is aware that his or her potential is limited so that external authority (religion) becomes a source of motivation. This normative-religious awareness is triggered by limitation of human being to understand universe. So many forces of universe are beyond human reason. Thus, it is God that governs universe. As far as madrasab is concerned, the awareness to perceive God as the creator is crucial in madrasab's curriculum which in turn shapes the minds of its students. It is madrasah that provides the students with the knowledge and conscience that religion (Islam) can explain everything that is not able to be explained by reason.

In this respect, Indonesian madrasah promote the model of education development which balances between worldly and hereafter affairs. This is applied by providing religious instruction as well as general and exact science simultaneously in the curriculum. ${ }^{15}$ By deeply

13 Ron Geaves, "Islam and Conscience," in Jayne Hoose (ed.), Conscience in World Religions (Notre Damme: University of Notre Damme Press, 1999), pp. 155-175.

${ }^{14}$ Lenn E. Goodman, Islamic Humanism (Oxford: Oxford University Press, 2005).

15 Subiyantoro, "Pengembangan Model Pendidikan Nilai Humanis-Religius Berbasis Madrasah," Cakrawala Pendidikan, Year XXXII No. 3 (November 2013). 
rooted upon Islamic teaching which remains contextual, the vision to combine modernity with religious culture is attainable in madrasah learning system. This also traces back to peaceful penetration of Islam into the archipelago inwhich acculturation is the key word. Thus, Islamic education in the form of madrasab maintains that harmony by accommodating and perseverance of humanism values. The result proves to be productive, in terms of its alumni. ${ }^{16}$

The political transformation in last twenty years has demanded education reform as well. Madrasah should be more flexible but remains persistent in preserving religious ethic as its core values. Humanism in modernizing education system and norms once conducted when transformation of madrasah took place by preserving Islamic instruction which is the core identity of madrasah. Thus, any further transformation should not touch this core basis. Implicitly speaking, the existence of madrasah in Indonesia simply affirms the relevance of Islam amidst the influx of modernity and all of its baggage. ${ }^{17}$

Discussing madrasah as social structure in Indonesian society must also deal with historical events that contributed to its existence. Indonesian society holds their culture dearly, including religion and values deeply rooted in it. Since religious values are instrumental, any social, cultural and scientific development will always be reasoned in terms of religious perspective as well as rational calculation. This is the advantage of madrasah compared to secular schools. In addition, since madrasah has a certain degree of liberty to adjust curriculum, madrasah can improvise deeper to provide moral guidance and values to create humanistic awareness.

Through madrasah, Islamic values are taught based on the sacred texts of the Holy Quran and Prophet tradition. There are at least two understanding about Islamic values when humanism is concerned; Islam as peaceful religion and its adaptability to social changes. ${ }^{18}$ Values of peace of humanistic peace have become the foundation of Islamic teaching. This has been translated as personal ethic as well and

\footnotetext{
16 Utami, "Kesadaran Kritis dan Humanisme.

${ }^{17}$ Karel A. Steenbrink, Pesantren, Sekolah, Madrasab: Pendidikan Islam dalam Kurun Moderen (Jakarta: LP3ES, 1986).

18 Jaenal Aripin, Syamsul Adham and Fauzan (eds), Kajian Islam Multidisipliner (Jakarta: Lemlit UIN Jakarta, 2009), p. 15.
} 
social norms as reflected through the growth of intellectualism, rationalism, innovation and the role of religion in Indonesian politics. When modernization now coined with liberation, Islam provides morality through, among other things, madrasah.

Sociologically speaking, there have been shifts in societal values from time to time. ${ }^{19}$ At this point, the understanding of Islam is preserved though schooling instruction in madrasah. Therefore, madrasah is crucial in building the humanist character of Indonesian society. Islam in Indonesia has been identified with tolerance because Indonesian culture is compatible with Islam. This combination will result in social humanism. Thus, madrasab still have strong bargaining position as an education institution in Indonesia. So far, madrasah remains important for Muslims in Indonesia because its ability to teach basic ritual and teaching which promotes peace and humanism. It creates harmony, security, tolerance, cooperation and mutual respect in social interaction. If peace is prerequisite for attaining prosperity and welfare, Muslims spread these concepts through madrasah.

Meanwhile, the teaching about social change is embedded in the emergence of Islam. The prophethood of Muhammad which brought about radical change is in essence a role model for madrasab education in responding social and historical reality. This reality is then revised and reconstructed, and finally solution is proposed. ${ }^{20}$ Since history will repeat in the course of time, morality becomes keyword in formulating response. Key concept such as justice, truth, honesty, harmony social responsibility, order, and prosperity are upheld. These values will remain relevant for Muslims which are institutionalized in madrasah.

In this regard, Islamic education of madrasah becomes a strategy to pass through values which are determinant for the future of Muslim society in Indonesia as well as to improve the way of life and humanistic civilization. Without Islamic education, it can be predicted that Indonesian society will be no different with the period of ignorance (jabiliyyab). In extreme level, the advancement or backwardness of a community is determined by its education. As Indonesian

${ }^{19}$ In this perspective, all religions underwent transformation in one way or another with the development of science and technology. Thus, if a person is not equipped with basic knowledge, his or her personal transformation could lead to dangerous consequences. Ther will be misinterpretation of doctrines in the context as well. Read A. Sudiarja, Agama di Zaman yang Berubah (Yogyakarta: Kanisius, 2006), p. 34.

${ }^{20}$ Aripin, Adham and Fauzan (eds), Kajian Islam Multidisipliner, p. 36. 
society is deeply attached to Islamic education, its positive image as peaceful and tolerant society is also shaped by madrasah. Its instruction of Islamic basic rituals and core values has enabled Muslims to achieve this image.

Based on the above description, it can be argued that the concept of Islamic teaching as promoted in madrasah reflects humanism. It is conducted with full awareness to build education system which reaches all element of society. This awareness is realized by the following features.

\section{Curriculum awareness and local wisdom of Indonesian Muslim Community}

Many element of madrasah curriculum is developed from pesantren. There are several pesantrens which also open madrasah. Its curriculum is dominated by core Islamic instruction. Still, they also observe national standard of education which has been jointly agreed among three ministeries as mentioned above. The decision to open madrasab in pesantren is a breakthrough since it required major transformation. ${ }^{21}$ However, with the curriculum is still determined by pesantren, the character building of Islamic values remain on touch.

Madrasah as a humanistic education has a function to provide education. This should be managed well. The expectation to realize good education requires qualified and competent teachers. Teachers must master the knowledge and know effective strategies to deliver it. The role of management to ensure performing teachers is a necessity. According to Paulo Freire, learning is a hard task. ${ }^{22}$ It requires systematic critical attitude and intellectual ability. Good learning process should involve students actively. Teachers only facilitate the transfer of knowledge to students. In constructivist theory of learning, knowledge cannot merely be transferred as such from teachers to students. ${ }^{23}$ Thus, students must be actively build their structure of knowledge according to their cognitive maturity. Simply said, students are not small bottle ready to be filled with materials by teachers.

${ }^{21}$ Maksum, Madrasah, p. 118. See also, Mujamil Qomar, Pesantren: Dari Transformasi Metodologi menuju Demokratisasi Institusi (Jakarta: Penerbit Erlangga, 2007), p. 108.

22 Paulo Freire, Politike Pendidikan: Kebudayaan, Kekuasaan dan Pembebasan (Yogyakarta: Pustaka Pelajar, 2007), p. 28.

${ }^{23}$ David C. Leonard, Learning Theories A to Z (Westport and London: Greenwood Press Publication, 2002), pp. 37-39. 
Until currently, madrasah is identical with managerial shortcomings and low intellectual achievements. ${ }^{24}$ These have been the main complaints about madrasah. Modernization finally came to madrasah to fix this issue. It tackles management and systemic issues. This process, though is perceived differently by Muslims, some welcome, while others are cautious if not resist. The spectrum in perceiving modernization in turn results in three types of madrasah; modern, mixed and traditional. This typology concerns concept, curriculum, method, and facilities. It can be said that even though madrasab in many aspects has been separated from pesantren, both institutions are of mutual benefit. Pesantren benefits from good management and methodology, whereas madrasah benefits from rich curriculum material. This is especially true for some pesantren adopting modernization process. ${ }^{25}$

\section{Madrasah Awareness on Marginal Society}

The curriculum material of madrasab needs good understanding about humanistic community in its surrounding. In this sense, it has been inevitable that Islam in Indonesia always accommodates local culture. The knowledge about Islam is, therefore, instrumental in shaping morality and values among Indonesian Muslims. Since the perception of Indonesian society about Islam is based on their education in madrasah, the role of madrasah in then also crucial. In this case, Islam is seen as religion which concerns the psychological aspect of its adherents. The process of includes the brotherhood among Muslims. With this assumption, interaction which is built among Muslims starts as early stage as they study in madrasah.

Sociologically speaking, many private madrasabs located in slums and poorer districts, which are usually poorly funded and managed, have significant role in educating poorer Muslim community as well. ${ }^{26}$ They help Muslims solve their daily problems. In contrast to government funded schools which are better funded and managed,

24 Abdul Wahid, "Manajemen Berbasis Madrasah" in Ismail SM, Nurul Huda, and Abdul Kholiq (eds), Dinamika Pesantren dan Madrasah, p. 262.

${ }^{25}$ Read Ali Anwar, Pembaruan Pendidikan di Pesantren Lirboyo Kediri (Yogyakarta: Pustaka Pelajar, 2011), p. 95.

26 Robert Kingham, "Basic Education in Indonesia," in Mathew Clarke \& Simon Feeny (eds), Education for the End of Poverty: Implementing all the Millenium Development Goals (New York: Nova Science Publisher, 2007), p. 108. 
these private madrasahs host less talented students. These students cannot compete with bright students to enroll in public schools which have limited seats. Even with several limitations, it is proven widely that the education in these madrasabs can lead students to have moral integrity based on Islamic universal values. Many national leaders and public figures with high moral integrity are the graduates of madrasah.

In the past, pesantren had successfully produced many influential personalities, such as Shaikh al-Nawawi al-Bantani, Shaikh Mahfudh Tarmasi ${ }^{27}$ up to contemporary figures such as Abdurrahman Wahid. Their reputation is beyond national boundary. These personalities who are graduates of madrasah are testament of the success of madrasah. Meanwhile, there is an idea to position madrasah to become agent of liberation and directed to build humanistic intellectualism among those less fortunate students. Islamic education can boost their morale and open up their mind about their situation which is prone to conflict. Therefore, Islamic education with its local content plays a crucial role in national development as well as its resilience.

Islam encourages religious education which is based on locality in the form of madrasab. Madrasab has been inseparable part of Indonesian Muslim identity not only as a Muslim but also as a citizen of Indonesia. This concept becomes the basic character of Indonesian Muslims. The combination of being Muslim and Indonesian at the same time results in aspiration of creating peaceful and harmonious life in Indonesia. In addition, the teaching process in madrasab also stimulates creativity, and creativity is important for innovation which is key element of civilization. According to Anthony Giddens, human being should become reflective creature which cognitively understands his or her potential and the surroundings, not just following the flow of life. ${ }^{28}$ Reflective way of thinking is emphasized by demanding critical and smart thinking to see social phenomenon with instinct, sensibility as well as sensitivity. This pattern provides motivation to cleverly reading the signs of the phenomenon in the surroundings. Later, the work of reason is to form strategy of implementing the possibilities in transforming Islamic values in Indonesia.

\footnotetext{
27 Abdurrahman Mas'ud, Menuju Paradigma Islam Humanis (Yogyakarta: Gama Media, 2003), p. 193.

28 Anthony Giddens, Teori Strukturasi: dasar-dasar Pembentukan Struktur Sosial Masyarakat (Yogyakarta: Pustaka Pelajar, 2010), p. 366.
} 
It should be noted that Islamic perspective about Indonesian culture is based on what the Muslims understand in education. Every culture has certain perspective to ensure its community so that they can live prosperously. This is can be achieved through education. The concept of prosperity is perceived through different situation and perspective. Through education prosperity is promoted and not limited to fulfilment of physical needs, but also intellectual and spiritual fulfilment through Indonesia. Islam also contains fascinating doctrine about education. Madrasab education is part of charity towards the unfortunates. ${ }^{29}$ This concept combines physical and spiritual aspect of human life. In physical aspect, Islam teaches alms zakat, cattle sacrifices, and other form of charity. Meanwhile, spiritual aspect of Islam encourages Muslims to prayer for salvation of fellow Muslims and to spread good word of Islam.

\section{Awareness to Form Culture Shift}

In the past, the appearance of madrasah cannot be separated from Muslim resistance against Dutch colonial power, especially a shift from armed resistance to nationalistic movement. Therefore, it is not unusual to understand Islamic movement with the basis of education, mainly pesantren and madrasah. The resistance is not only launched through armed campaign but also discourse campaign which could motivate Indonesian community. Education became crucial in the effort to bring about radical change. This was conducted in pesantren that had autonomous and independent tradition. Upon those phenomena, Paulo Freire once said that education could bestow human being with choice in life and character building. ${ }^{30}$ Islamic education of madrasah can also be understood as this lifelong change as well. Equipped with knowledge, information and vision, human being will reshape his or her surroundings because human being will always transform through ideas by creating innovations. For mule community, such processes are done in madrasahs.

\footnotetext{
${ }^{29}$ Hilman Latief and Alpha R. Amirrachman, "Islamic Philanthropy and the Rights to Education: Modalities of Education Provision for Underprivileged Groups in Indonesia," in Kun Eng Kuah and Jason Eng Thye Tan (eds), Educating Marginalized Communities in East and Southeast Asia (London \& New York: Routledge, 2017), p. 38.

30 Paulo Freire, Politik Pendidikan: Kebudayaan, Kekuasaan dan Pembebasan (Yogyakarta: Pustaka Pelajar, 2007), p. 195. This view leads to efforts to freeing human being though humanistic education, which is the one suitable with the needs of human being.
} 
During Suharto's New Order period (1966-1998), the existence of madrasab was crucial in preventing the spread of communism. It counter balanced rationalism with spiritual and divine force. Islam signifies worship, social interaction as well as environmentalism. This process happened even though the political atmosphere was not favorable. ${ }^{31}$ Foundations and private agencies had important role in the sustainability and development of madrasah. The joint decree of three ministers in 1975 further acknowledged the important role of madrasah as education institution in Indonesia as well as its identical position with secular schools. ${ }^{32}$

The combination of private individuals and support of government, madrasah tries its best to improve quality and relevance. One of the efforts is to equip madrasab with facilities that meet national standard, something which was only achievable by government fullyfunded schools or private schools owned by rich foundations. In doing so, madrasah retains its distinct curriculum, a curriculum which emphasizes on Islamic instruction. This aspect then is implanted with the national curriculum set by government. This results in innovations which differ from one madrasah to another. For instance, in Banyumas, Central Java, many private low-funded madrasabs were opened due to the demand to equip students with Islamic education, even though schools are also available in the districts. ${ }^{33}$

For madrasab in rural areas with limited funding, the role of madrasah is even far more crucial. As virtually the main provider of education, madrasab has the role to educate students whose future is depend on it. Thus, there should be ways to provide good education in very limited funding. Madrasah pulled it out. Not only it successfully educates students in Islamic as well as general subjects, it also grows students' motivation to education, enabling them to dream for bright future.

The potential of madrasah is better exposed when it is coupled with pesantren. The development of pesantren in last two decades

\footnotetext{
31 Mudjahirin Thohir, Orang Islam Jawa Pesisiran (Semarang: Puslit Sosial Budaya Lembaha Penelitian Universitas Diponegoro in collaboration with Fasino, 2006), pp. 215-216. Read also Kholid Mawardi, Mahzab Sosial Keagamaan NU (PurwokertoYogyakarta: STAIN Pruwokerto Press in collaboration with Grafindo, 2006).

32 Sunhaji, Managemen Madrasah, pp. 75-76.

${ }^{33}$ Ibid.
} 
has been significant. Many pesantrens now are hosts to good madrasahs. Many pesantrens also upgrade their education from mere informal education to be more well-managed ones. Their teaching and learning process, curriculum and facilities are now improved. 34

From this improvement, there is growing awareness that education is not only about acquiring knowledge, but also qualification to attain better quality of life. As there are growing number of madrasah is located and managed by pesantren, the two Islamic education institutions are inseparable in a good way. Madrasah provides formal education with qualification acknowledged by government whereas pesantren gives instruction and experience of Islam and its morality. The conventional arrangement is that in the morning students would study in madrasah. And after school hours students will be educated pesantren curriculum and pesantren way of Islam. The graduate of madrasab-pesantren will not only academically qualified but also being a good practicing Muslim with sufficient knowledge of Islam.

Having exposed its potential and excellence in combing formal education with Islamic instruction and way of life, many segments of Indonesian community start to see madrasah not only as an alternative, but the main choice of education. They see, that in information technology era when the world virtually has no boundary, moral decadence among youth is common place. Thus there is a need of an education with combine knowledge and morality. Madrasah fits that criteria. Education can become a method to free oneself from limitations. It creates awareness to shape culture and finally to start a civilization. ${ }^{35}$ Education is an important because it prepare new generation. Madrasah, which is anchored in Islamic tradition provides qualification as well as morality which complement each other. Ultimately, madrasah as education institution values tolerance and diversity as part of humanism.

\section{By-product Role: Madrasah and Social Mobilization}

The social humanism as developed by Muslims through madrasah has resulted in an unprecedented by-product role of social

\footnotetext{
34 See in Mohmmad Achyat Ahmad, Liberalisasi Islam di Pesantren (Pasuruan: Pustaka Sidogiri, 1434H), p. 38.

35 Muhammad Fuad, Pendidikan sebagai Transformasi Sosial: Telaah terhadap Filsafat Pendidikan Paulo Freire (Jakarta: Universitas Indonesia Press, 2010).
} 
mobilization among them. The existence of madrasab is disassociated from the way Muslims expand their participation in public sphere. The massive growth of madrasah during the post-colonial period can be seen as the Muslims' strategy of demanding the State to the same access and treatment to public officials and governmental posts previously dominated by graduates of non-madrasah educational institutions. Based on a release of the Education Management Information Center (EMIS), Directorate General of Islamic Education, it is found out that there are more than 78.000 madrasabs spread all over the country in all levels and types, from early childhood schools to Islamic junior and senior high schools. ${ }^{36}$ Some of them are government funded, while the majority is private-owned. In the context of educational institution, the existence of madrasab contributes to $27,52 \%$ of Indonesia's total number of educational schools.

Based on the data above it can be argued that madrasabs are on the move to center of power relation amidst the configuration of Indonesia's education in general. One of the striking features that mark a departing point in the development of madrasabs is when they were acknowledged as equivalent to the existing education in Indonesia's general schooling system with the enactment of the Act No 2 Year 1989. This Act has paved the way for madrasabs to move more deeply into the education system at the national level. ${ }^{37}$ The government acknowledgment to madrasah system is not without long and tenuous efforts from Muslims. They have demanded the government in order to give them an equal treatment to madrasabs as the general schools have been treated. In the eyes of Muslims in general, the government had given an unequal treatment to the the two educational systems: non-religious education under the Ministry of Education and Culture and madrasabs under the Ministry of Religious Affairs.

The enactment of the Act No 2/1989 proves to have resulted in significant impacts on the development and transformation of madrasah in Indonesia. For the first time in Indonesia's history of education, the graduates of madrasab are treated equally with their counterparts from secular schooling system. As a result, this formal acknowledgment leads to the massive mobilization among Muslims to enroll themselves

\footnotetext{
${ }^{36}$ http://emispendis.kemenag.go.id/emis2016v1/, accessed on 27 March 2017.

37 Muhammad Sirozi, Politik. Kebijakan Pendidikan di Indonesia: peran tokoh-tokoh Islam dalam penyusunan UU No 2/1989 (Leiden-Jakarta: INIS, 2004), pp. 148-154.
} 
in whatever educational institution they wish. This transformation is also characterized by massive enrolment of madrasah as well as pesantren graduates in some elite universities such as Universitas Indonesia (UI), Universitas Gadjah Mada (UGM), Institut Teknologi Bandung (ITB), and others. Many of them have even succeeded in their later secular education and have strategic position as bureaucrats, economists, politicians, university professors, researchers and some other important positions. The equal treatment of madrasab by the government through the Act No. 2/1989 makes the social mobilization among Muslims into positions or places previously untraveled is unstoppable. It must be acknowledged that the enactment of this Act benefits madrasab a lot in Indonesia to mobilize themselves into wider exposure to public sphere.

Scrutinized more closely, the development of social humanism by Muslims through madrasah can be seen as a way they maintain and safeguard their religious identity. ${ }^{38}$ Madrasab is thus instrumentalised by Muslims as a means of protecting their existence in terms of religious identity through which they teach and sustain whatever necessary to younger generations in terms of theological belief, ritual practices and cultural features. All of these form a salient identity among Muslims which differ themselves from other groups of society, either internally among fellow Muslims or externally outside of Muslims. It is through madrasah that Muslims strengthen and reiterate the identity of being devout Muslims (santri). Therefore, it can be argued that madrasab is used by Indonesian Muslims as a self-defense mechanism in facing the invasion of non-santri identity.

It is within the function of social humanism that the function of madrasah has existed as a result of contest and competition among the two schooling systems in Indonesia: madrasah under the auspices of Ministry of Religious Affairs (MoRA) on the one hand, and secular schools under the Ministry of Education and Culture. The competition of two is unavoidable particularly in regards to the accumulating demands of society and different product they offer to the stakeholders. While the secular schools can only offer the mastery of secular subjects among the students, madrasab offers secular as well as religious subjects which can be its comparative advantage. This is the

${ }^{38}$ Maksum, Madrasah, 149. 
major explanation behind the massive expansion and development of madrasab in the landscape of Indonesian education system.

\section{Conclusion}

From the explanation above it can be summed up as follows. Firstly, madrasab has played dual role as a means of hoisting and raising up social humanism as well as social mobilization at once. In the beginning, madrasah might be perceived by Muslims as a means of safeguarding the Islamic identity in facing the challenge of external threats. This function however expands the function of madrasah not only as a means of self-defense mechanism but also as an effective way of social mobilization among them. The enactment of the Act No. 2/1989 on the National Education System serves as a departing point where madrasah receives an equal treatment from the government especially in terms of formal recognition and access to public sphere in general. This Act proves to have benefitted madrasah a lot in making its pace in the competition of schooling system in Indonesia.

Secondly, madrasah has contributed to the making of Indonesia's culture and cultivating the concept of "authentic self" which essentially differs from the concept of "the other." It is within this context that madrasab is projected to have promising future for the country. It offers a unique and robust way of character building among the students. The graduates of madrasah prove to have survived in an open and harsh competition facing the secular schooling system. A significant bulk of its graduates has also had accessed to some strategic posts and bureaucratic position in the country that can support and even strengthen the position of madrasab in the configuration of education system in Indonesia. In other words, this country does not have any other option except relying on madrasah in building its nation in the future. []

\section{References}

\section{Books and Articles}

A. Sudiraja. Agama di Zaman yang Berubah. Yogayakarta: Kanisius, 2006.

Ahmad, Mohammad Achyat. Liberalisasi Islam di Pesantren (Refleksi Pemikiran Santri). Pasuruan: Pustaka Sidogiri, 1434H. 
Anwar, Ali. Pembaruan Pendidikan di Pesantren Lirboyo Kediri. Yogyakarta: Pustaka Pelajar, 2011.

Aripin, Jaenal, Syamsul Adham and Fauzan (eds). Kajian Islam Multidisipliner. Jakarta: Lemlit UIN Jakarta, 2009.

Azra, Azyumardi. "Pesantren and Madrasa: Muslim Schools and National Ideas in Indonesia." in Robert W. Hefner \& Muhammad Qasim Zaman (eds.). Scooling Islam: The Culture and Politics of Modern Muslim Education. Princeton, New Jersey: Princeton University Press, 2007.

Baharudin. Dikotomi Pendidikan Islam: Historisitas dan Implikasi pada Masyarakat Islam. Bandung: PT Remaja Rosda Karya, 2011.

Departemen Pendidikan dan Kebudayaan. Kamus Besar Bahasa Indonesia Jakarta: Gramedia, 2015.

Freire, Paulo. Politik Pendidikan: Kebudayaan, Kekuasaan dan Pembebasan. Yogyakarta: Pustaka Pelajar, 2007.

Fuad, Muhammad. Pendidikan sebagai Transformasi Sosial: Telaah terbadap Filsafat Pendidikan Paulo Freire. Jakarta: Universitas Indonesia, 2010.

Geaves, Ron. "Islam and Conscience." in Jayne Hoose (ed.). Conscience in World Religions. Notre Damme: University of Notre Damme Press, 1999.

Giddens, Anthony. Teori Strukturasi: Dasar-dasar Pembentukan Struktur Sosial Masyarakat. translated by Maufur and Daryatno. Yogyakarta: Pustaka Pelajar, 2010.

Goodman, Lenn E. Islamic Humanism. Oxford: Oxford University Press, 2005.

Huda, Nurul. "Madrasab: Sebuah Perjalanan untuk Eksis" in Ismail SM, Abdul Kholiq (eds). Dinamika Pesantren dan Madrasah. Semarang: Faculty of Tarbiyah IAIN Walisongo in collaboration with Pustaka Pelajar, 2002.

Ismail SM et al. Dinamika Pesantren dan Madrasah. Semarang: Fakultas Tarbiyah IAIN Walisongo in collaboration with Pustaka Pelajar, 2002.

Kahar. "Pendidikan Islam dalam Pandangan Pendidikan Nasional." Jurnal Al-Qolam, 8:1 (2016). 
Khariri. Islam dan Budaya Masyarakat. Purwokerto-Yogyakarta: STAIN Purwokerto Press in collaboration with Fajar Pustaka, 2008.

Kingham, Robert. "Basic Education in Indonesia." in Mathew Clarke \& Simon Feeny (eds). Education for the End of Poverty: Implementing all the Millenium Development Goals. New York: Nova Science Publisher, 2007.

Latief, Hilman and Alpha R. Amirrachman. "Islamic Philanthrpy and the Rights to Education: Modalities of Education Provision for Underprivileged Groups in Indonesia." in Kun Eng Kuah and Jason Eng Thye Tan (eds). Educating Marginalized Communities in East and Southeast Asia. London \& New York: Routledge, 2017.

Leonard, David C. Learning Theories A to Z. Westport and London: Greenwood Press Publication, 2002.

Maksum. Madrasab: Sejarah \& Perkembangannya. Jakarta: Logos Wacana Ilmu dan Pemikiran, 1999.

Mawardi, Kholid. Mahzab Sosial Keagamaan NU. PurwokertoYogyakarta: STAIN Purwokerto Press in collaboration with dengan Grafindo, 2006.

Murni Rachmawati. "Humanisme (Kembali) dalam Arsitektur." Jurnal Nalars, 9:2 (July 2010): pp. 103-116

Nata, Abuddin. Kapita Selekta Pendidikan Islam: Isu-isu Kontemporer tentang Pendidikan Islam. Jakarta: Raja Grafindo Persada, 2012.

Qomar, Mujamil. Pesantren: Dari Transformasi Metodologi menuju Demokratisasi Institusi. Jakarta: Penerbit Erlangga, 2007.

Saridjo, Marwan. Bunga rampai Pendidikan Agama Islam. Jakarta: CV Amissco, 1996.

Sirozi, Muhammad. Politik Kebijakan Pendidikan di Indonesia: peran tokobtokoh Islam dalam penyusunan UU No 2/1989. Leiden-Jakarta: INIS, 2004.

Sri Utami, "Kesadaran Kritis dan Humanisme dalam Globalisasi: Kajian Pemikiran Edward W. Said tentang Worldliness Humanism." in Proceeding the 5th Internasional Conference Indonesian Studies: "Ethnicity and Globalization".

Steenbrink, Karel A. Pesantren, Sekolah, Madrasab: Pendidikan Islam dalam Kurun Moderen. Jakarta: LP3ES, 1986. 
Subiyantoro. "Pengembangan Model Pendidikan Nilai HumanisReligius Berbasis Madrasah." Cakrawala Pendidikan, 32:3 (November 2013).

Sunhaji. Managemen Madrasah. Purwokerto-Yogyakarta: STAIN Purwokerto Press in collaboration with Grafindo, 2006.

Thohir, Mudjahirin. Orang Islam Jawa Pesisiran. Semarang: Puslit Sosial Budaya Lembaga Penelitian Universitas Diponegoro in collaboration with Fasino, 2006.

Wahid, Abdul. "Manajemen Berbasis Madrasab", Ismail SM (ed), Dinamika Pesantren dan Madrasah, Semarang: Fakultas Tarbiyah IAIN Walisongo in collaboration with Pustaka Pelajar, 2002. 